\title{
Green-tuff landslide areas are beneficial for rice nutrition in Japan
}

\author{
KAZUE TAZAKI \\ Department of Earth Sciences, Faculty of Science, Kanazawa University \\ Kakuma, Kanazawa, Ishikawa 920-1192 Japan \\ Manuscript received on September 29, 2005; accepted for publication on March 13, 2006; \\ presented by OTHON H. LEONARDOS
}

\begin{abstract}
Japanese Islands are covered with weathered volcanic rocks and soils. Terraced rice field are located in green-tuff areas which are very fertile but where landslides occur associated to strong earthquakes. The Xray diffraction and X-ray fluorescence analyses of the soils in landslide area identified predominant smectite and $\mathrm{Mg}, \mathrm{Al}, \mathrm{Si}, \mathrm{K}, \mathrm{Ti}, \mathrm{Mn}$ and $\mathrm{Fe}$ are main components. The rice leaf showed that $\mathrm{S}, \mathrm{Cl}, \mathrm{K}$ and $\mathrm{Ca}$ play important roles for nutrients in the area. Drainpipe systems have set up in the green- tuff areas to reduce the risks of landslides. Reddish brown microbial mats inhabited bacteria and diatom in the drainpipe outlets. The microbial mats are rich in $\mathrm{Fe}$ and $\mathrm{PO}_{4}^{3-}$. The iron bacteria in the ground water have a high metabolic rate suggesting that the weathering materials were produced by not only physical and chemical influence but also by microorganism. Many microorganisms attach to mineral surfaces and show their high impact in the water mineral chemistry in the landslide area. Bacteria in the green-tuff over landslide area play important roles for sustainable agriculture including rice nutrition.
\end{abstract}

Key words: green-tuff, terraced rice field, landslide, microbial materials.

\section{INTRODUCTION}

Volcanic rocks are predominant in Japanese Islands. Weathered volcanic rocks cover mostly the surface of the Japanese Islands. Terraced rice field are commonly located over volcanic ashes, pumice and green-tuffs. The alteration of those rocks generates fertile soils. Otherwise, this area is tectonic active and tragic landslide accidents caused by strong earthquakes (Shoji et al. 1993; Fig. 1) occurred. Earthquakes (up to 7 a magnitude of 7) occurred in Niigata at the Japan Sea Coast, on $25^{\text {th }}$ October, 2004. In this area, green-tuff formation occurs and a famous agricultural district which produces high quality rice is situated. In this mountainous Japanese Country, in flat land, rural houses and rice field are

E-mail: kazuet@kenroku.kanazawa-u.ac.jp often built under steep slop.

Factors determine food security and food quality come from the natural factors, such as soil quality, climate stability, and both water quality and quantity, associated with modern agrotechnology. The green-tuff areas are the most suitable districts for farming of rice. We have growing problems related to chemical nutrient oversupply in Japanese farming. It is the time to think about natural rocks and minerals for crops. Our soils were rich, being derived in large part from volcanic rocks that formed the Japan Alps along tectonic active fault. These young soils were full of unweathered minerals capable of slowly releasing nutrients over a long period of time as they were broken down. All forms of life need a complex array of mineral nutrients and 


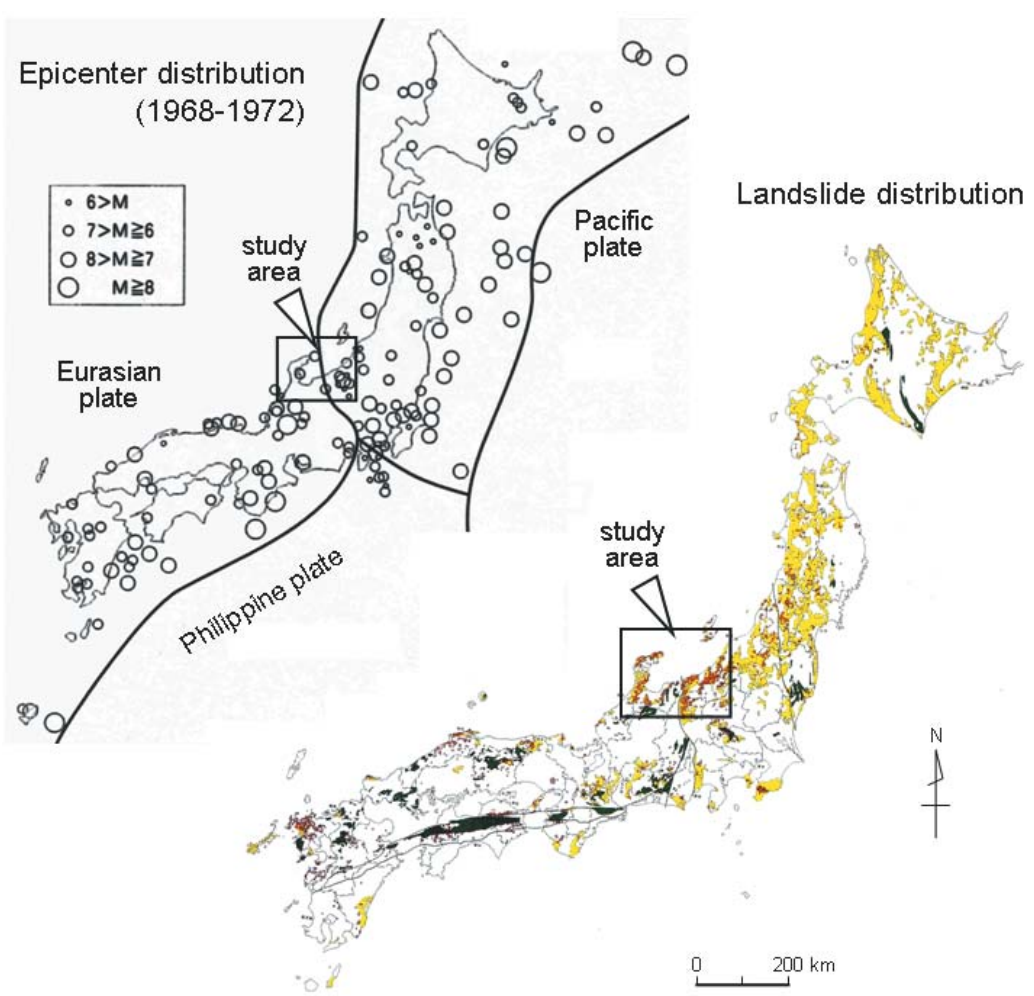

Fig. 1 - Earth quakes in tectonic active areas and landslide distribution in Japanese Island. Arrows indicate study areas.

where the soils are poor and subsistence agriculture has been practiced for a long period of time, many of these nutrients are simply no long in the soils.

Geochemical map of Japan (Geological Survey of Japan 2004), using river sediments, provides us with valuable information on agricultural research conducted with some of the minerals and rocks locally available in Hokuriku district in Japan (Fig. 4). The maps with its extensive and up-to-date references are an excellent starting point for integrated agricultural research and development work in Japan, for soil scientists, geoscientists, and engineers. The concept of agrogeology certainly needs more recognition and we must do more to foster trans-disciplinary research and development to tackle our environmental problems and address issues of food security. Soil remediation is critical to the global problem of food security. We must use the right "rocks" on the right "crops".

Microorganisms in microbial mats can grow and survive in the natural environment including some of the most extreme and adverse environment on the Earth (Ohta et al. 2003). Recently, in the most of cases microorganisms have been used as indicators for the investigation of environmental conditions (Khristoforova 1999). The precipitation of minerals by living organisms is widespread phenomenon that is generally referred to as biomineralization. The significance of bacterial biomineralization is emphasized by the fact that microorganisms are the most abundant life form on the surface of the Earth and live in a variety of environments. Diatoms precipitate silicon on their cell walls, whereas bacteria can accumulate $\mathrm{Fe}, \mathrm{Mn}, \mathrm{Sr}$, and some other elements in/on to the cell (Beveridge 1999). 
In this study, I propose new approaches for soil remediation using microbes in the drainpipe outlets over the landslide area, not just the use of chemical fertilizers. Takayanagi in Niigata prefecture is a typical landslide area for microbial study, where the drainage systems were established to prevent mudslide occurrence. SEM-EDX observations revealed the diversity of ecosystem, which depends on the characteristics of water and soils with useful elements for the right crops.

\section{MATERIALS AND METHODS}

The samples of river sediments, soils and rice leaf around landslide area, and microbial mats of drainpipes were collected from Takayanagi in Niigata prefecture, Japan. Water drainage system (through the pipe) was established in the landslide areas of Takayanagi and Oh-hirota in Kashiwazaki, Niigata (H. Segawa et al., unpublished data) (Fig. 2). The numerous drainpipes were set up in the locality to inhibit mudslide occurrence (Fig. 3A, B). Each drainpipe carried groundwater all the time resulting the formation of microbial mats in the outlet of the pipes (Fig. 3C). Different colored microbial mats with ground waters were collected from those drainpipe outlets for analysis. The drainpipes, $50 \mathrm{~m}$ in length, were radially set up for drained groundwater off. The microbial mats are light reddish brown (point 1), reddish brown (point 2), greenish brown (point 3), and green microbial mats (point 4) in color, respectively.

The pH, Eh, DO (Dissolved Oxygen), and water temperature were measured in the field using a HORIBA portable inspection meter. Microbial mats were examined with a polarizing optical and fluorescence microscope (Nikon OPTIPHOT2 EFD3). The sample stained with 4', 6-diamidino2-phenylindole (DAPI) is observed through an episcopic fluorescence microscope. DAPI method stains the DNA in bacterial cells, and blue fluorescence under ultraviolet light $(365 \mathrm{~nm})$ indicates metabolically active bacteria.

A low-vacuum scanning electron microscope

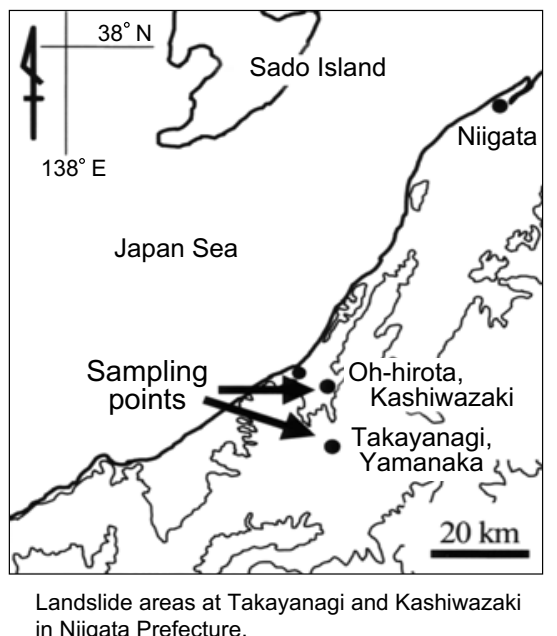

Fig. 2 - Locality map of landslide areas shows sampling points at Takayanagi and Kashiwazaki in Niigata prefecture in Japan.

(LV-SEM, JEOL JSM-5200LV) equipped with an energy dispersive X-ray spectrometer (Philips EDAX PV9800EX) (SEM-EDX) was used to observe the micro morphology of rice leaf, and its chemical composition. The samples were mounted on stubs using carbon tape and examined at accelerating voltages of $15-25 \mathrm{kV}$. Mineralogical investigations of river sediments and microbial mats were performed by X-ray powder diffraction (XRD). A Rigaku Rinto 1200 X-ray diffractometer $\left(\mathrm{CuK}_{\alpha}\right.$ radiation) operating at $40 \mathrm{kV}$ and $30 \mathrm{~mA}$, and a scanning speed of 1-20 sec. / 0.02 degree, was used. Chemical composition of the samples was analyzed using the energy-dispersive X-ray fluorescence (ED-XRF) analyzer (JEOL JSX 3201) applying $\mathrm{Rh}$ radiation at $30 \mathrm{kV}$. The chemical composition of microbial mats was determined and the quantity of $\mathrm{PO}_{4}^{3-}$ was made using an automatic gas chromatography.

\section{LANDSLIDE Sites AND EPICENTER DISTRIBUTION IN JAPAN}

Locality maps of landslide sites and epicenter distribution were shown in Fig. 1, indicating number of Earth quakes (1968-1972) in tectonic active areas set a limit to magnitude between 6 and 8 . 

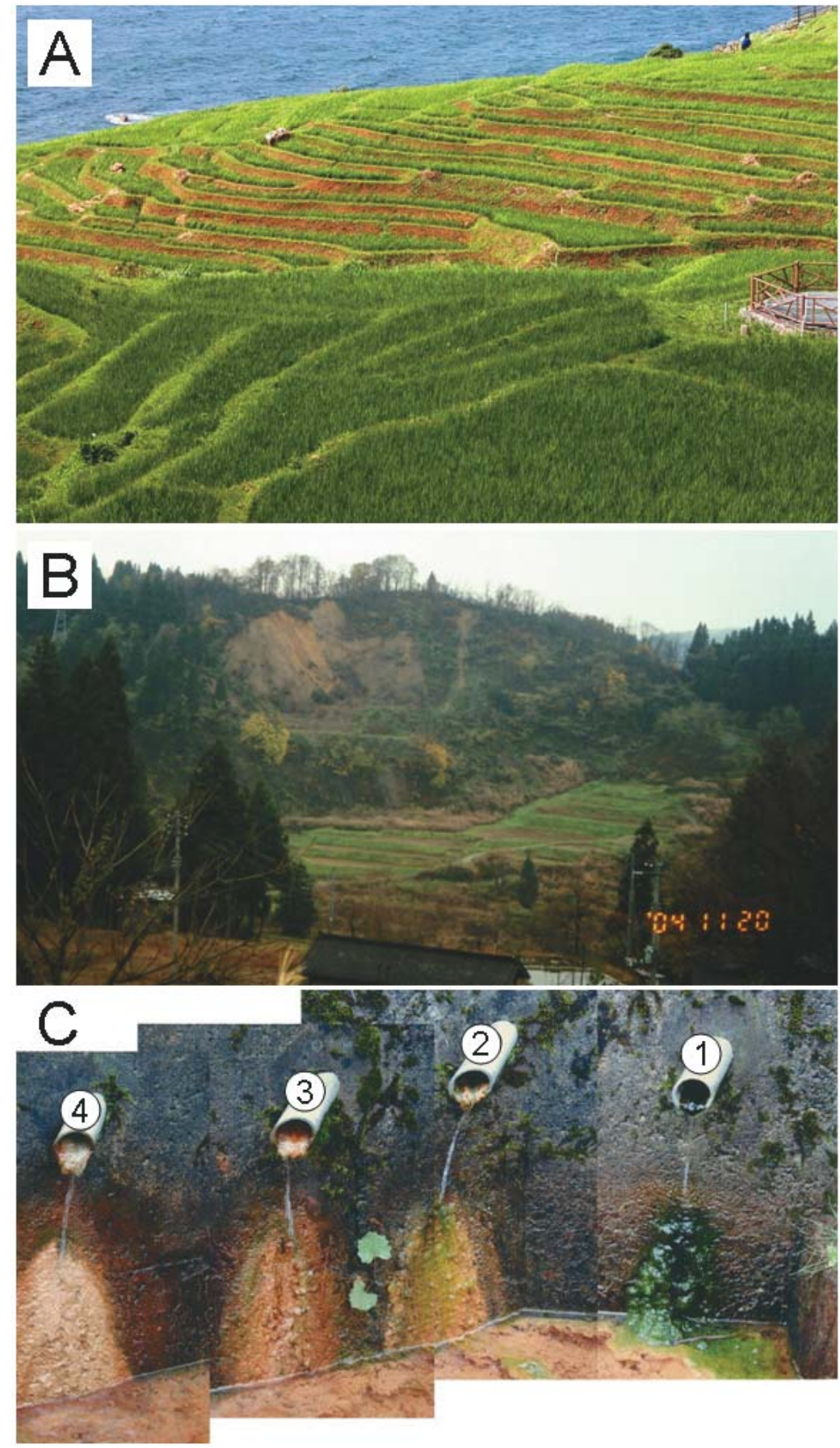

Fig. 3 - Outcrop views of landslide areas with terraced rice field at Noto pen insure (A), largely slide down the hill beside rice fields in Tochio, Niigata Prefecture, by earthquake in 2004 (B), and drainage pipes at landslide area in Takayanagi, Kashiwazaki in Niigata (C). The geological column correlated with the outcrop indicating green-tuff formation. 
Most earthquakes are located in tectonically active areas and volcanic activity is a process generally related to plate tectonics. Most volcanoes are located at plate junctions where magma is produced as spreading or sinking lithospheric plates interact with other earth materials. The occurrence of landslides is closely related to the geological conditions. Depending on the geological features, landslides are largely classified into 3 categories, i.e. (1) Tertiary system landslide, (2) Fracture zone landslide, and (3) Hydrothermal zone landslides. Tertiary system landslide occurs in Hokuriku district, associated with soft rock prone to rapid weathering, but the movement tends to be slow (Koide 1955). Tertiary system landslide commonly occurs at Greentuff system of Noto Peninsula in Ishikawa prefecture and Kashiwazaki in Niigata prefecture, Japan Sea cost, where extensively form terraced rice fields (Figures 2 and 3).

\section{GEOCHEMICAL MAPS OF HOKURIKU DISTRICT}

Geochemical map of Japan was open to the public with valuable information on agricultural research conducted with some of the minerals and rocks locally available in river sediments (Geological Survey of Japan 2004). The maps with its extensive and up-to-date references are starting point for integrated agricultural research of "Rocks for Crops" in Hokuriku district, Japan. Some of elemental maps are shown in Fig. 4. The $\mathrm{MgO}, \mathrm{CaO}, \mathrm{P}_{2} \mathrm{O}_{5}, \mathrm{MnO}$, and $\mathrm{Fe}_{2} \mathrm{O}_{3}$ maps are closely interrelated with same tendency of high concentrations in Noto Peninsula and landslide areas at Kashiwazaki and Takayanagi in Niigata prefecture. On the other hand the $\mathrm{K}_{2} \mathrm{O}$ map is quite different from those elemental maps indicating low concentration of $\mathrm{K}_{2} \mathrm{O}$ at landslide areas, suggesting poor in K-minerals.

\section{RESULTS}

X-Ray Diffraction Analyses (XRD) of SoIls AT RICE FIELD IN LANDSLIDE AREA

Six soil samples were collected from rice field in landslide area in Niigata prefecture, were analyzed by XRD (Fig. 5). Quartz and feldspars are main minerals with traces of clay minerals in all bulk samples. In $<2 \mu \mathrm{m}$ clay fraction of the samples clearly show abundant $0.14 \mathrm{~nm}$ clay minerals under non-treatment. The $0.14 \mathrm{~nm}$ diffraction peak shifted to $0.17 \mathrm{~nm}$ after EG treatment, is consistent with smectite. A small amount of $0.10 \mathrm{~nm}$ (mica clay minerals) and $0.71 \mathrm{~nm}$ kaolin minerals were found in the soils.

The microbial mats were collected from drainpipe system of the landslide areas of Takayanagi and Oh-hirota in Kashiwazaki, Niigata. Different colored microbial mats from those drainpipe outlets showed the almost amorphous XRD pattern, whereas relatively strong peak at $0.15 \mathrm{~nm}$ shifts to $0.17 \mathrm{~nm}$ after EG treatment was found as smectite at drainpipe $40 \mathrm{~m}$ away from outlets (Fig. 5 bottom). A small amount of mica clay minerals $(0.10 \mathrm{~nm})$ and kaolin minerals $(0.7 \mathrm{~nm})$ are associated with abundant smectite. Note that XRD patterns of rice field soils are similar to those of microbial mats (40 m away), in which smectite was identified.

\section{ENERgy Dispersive X-RAY Fluorescence ANALYSIS (ED-XRF)}

The untreated soil samples from rice field dispersed on Mylar film were analyzed by ED-XRF showed that $\mathrm{Al}_{2} \mathrm{O}_{3}, \mathrm{SiO}_{2}$, and $\mathrm{Fe}_{2} \mathrm{O}_{3}$, are main components, associated with traces of $\mathrm{MgO}, \mathrm{K}_{2} \mathrm{O}, \mathrm{CaO}, \mathrm{TiO}_{2}$, $\mathrm{MnO}$, and $\mathrm{ZnO}$ in silicate rocks (Fig. 6). The EDXRF chemical results are agreed with XRD mineralogical data.

\section{SCANNING ELECTRON Microscopy EQUiPPED WITH ENERGy DisPersive X-RAY ANALYSIS (SEM-EDX) OF RICE LEAF}

The SEM-EDX observation of rice leaf revealed the microstructure of stoma, spotted surface, and coating adhesion materials with their chemical compositions (Fig. 7). Surface of rice leaf shows abundant stoma with regularity composed of $\mathrm{Al}, \mathrm{Si}, \mathrm{S}$, $\mathrm{Cl}, \mathrm{K}$, and $\mathrm{Ca}$. The $\mathrm{K}$ content in the adhesion materials is 4 times richer than $\mathrm{Ca}$ content. The chemical 

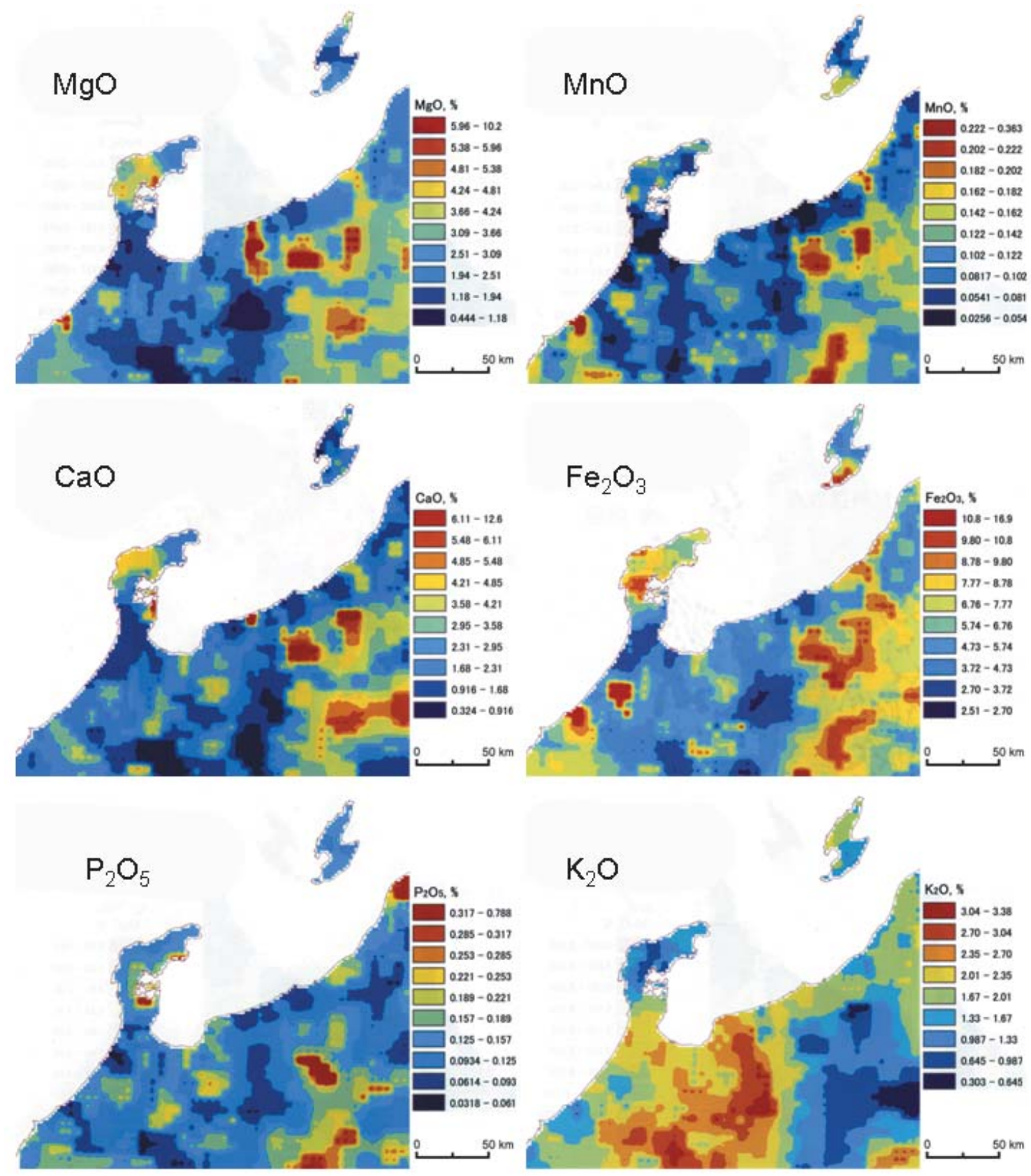

Geochemical maps of Hokuriku district, using river sediments (Geological Survey of Japan, AIST, 2004).

Fig. 4 - Geo-chemical maps of river sediments at Hokuriku district, Japan. River sediments were used for the chemical analyses (Geological Survey of Japan 2004; open to the public). 


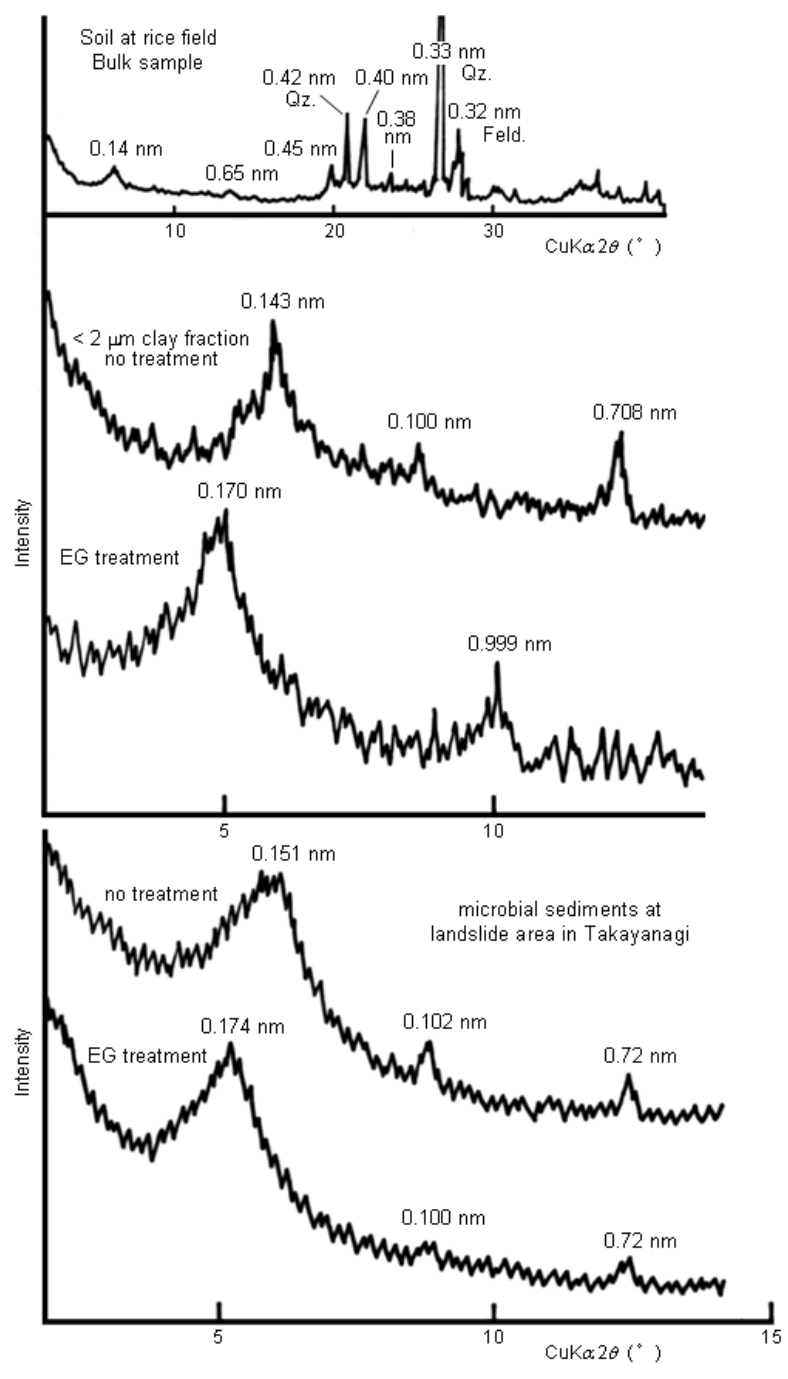

Fig. 5 - X-ray powder diffraction patterns of rice field soils in Niigata and microbial mats at landslide area in Takayanagi, Niigata, showing bulk and $<2 \mu \mathrm{m}$ fraction data with no treatment and after E.G. treatment.

composition data suggest us what kind of elements are essential for growth of rice leaf in the field.

Optical and Fluorescence Microscopic OBSERVATIONS OF MicRobial MATS

Four kinds of microbial mats from drainage pipes in landslide area were observed under optical and fluorescence microscopy showing various microorganisms inhabit in each different water systems (Fig. 8 upper). The slightly reduced redox states of the pipe 3 and 4 were confirmed by Eh values of 140-190 mV and dissolved oxygen levels of 2-3 mg/l at pH 6.4-6.5. The other ground water in the pipes 1 and 2 indicated oxidized conditions, such as Eh 301-456 mV and DO 3.8-6.7 mg/l, indicating the diversity of ecosystem depend on characteristics of water systems.

The microbial mats were mainly composed of colonies of right brown or transparent microbes associated with filamentous microbes (Fig. 8 bot- 
XRF chemical analyses of soils at rice field in Gotanda, Niigata (Oct. 2004).

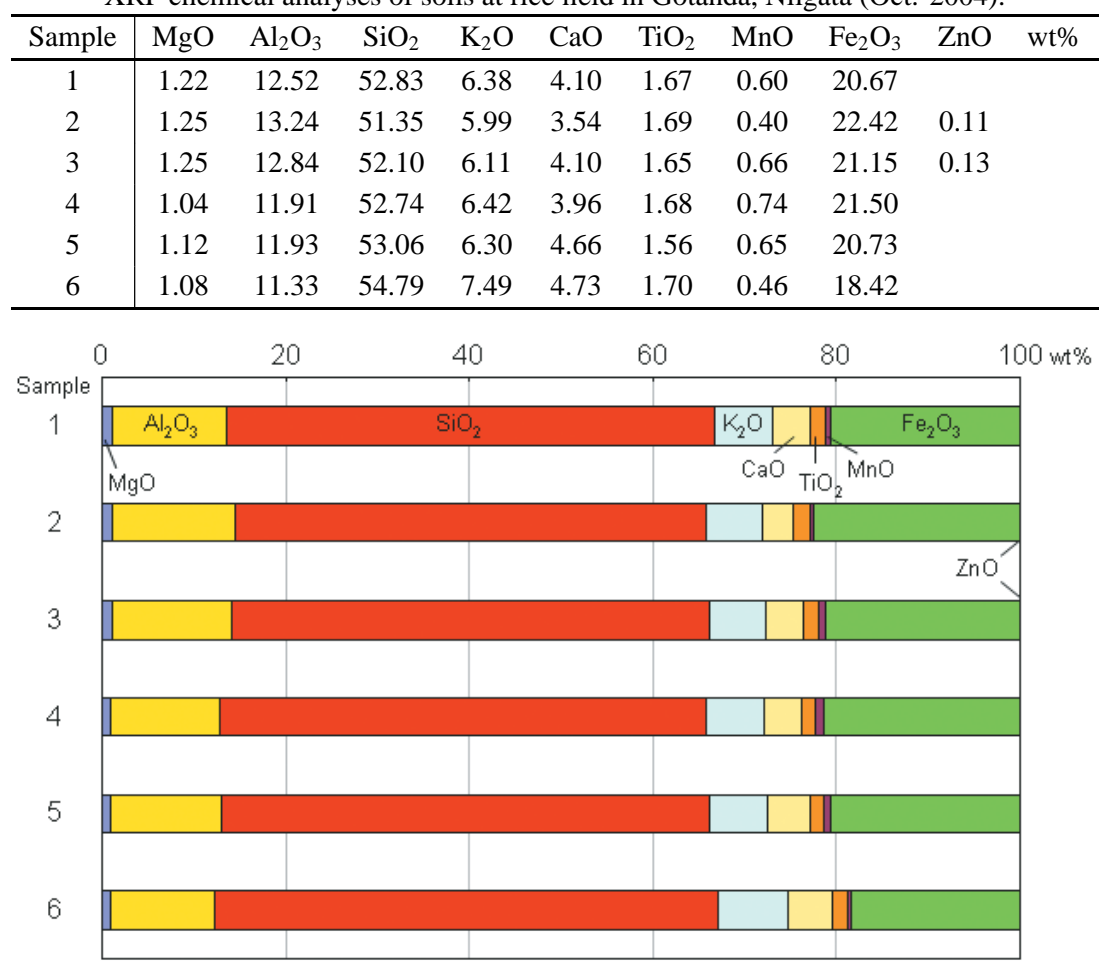

Fig. 6 - X-ray fluorescence analyses (XRF) of soils from six rice fields in Niigata, Japan, show similar chemistry.

tom). Optical micrographs showed abundant diatom in pipe 1 whereas iron oxidized bacteria (Leptothrix ochracea) associated with algal filaments, diatoms, and bacteria of coccus and bacillus type in pipe 3. The microbes fluoresced red when exposed to light of 510-560 $\mathrm{nm}$ wavelengths, indicating that the microbes contain chlorophylla. The various microbes were tentatively identified on the basis of their morphologies (Holt et al. 1994) as filamentous algae (15-20 nm in width), filamentous algae (10-100 $\mathrm{nm}$ in diameter), Cyanobacteria (20 $\mathrm{nm}$ in width), and bacteria having coccus or bacillus morphology ( $<10 \mathrm{~nm}$ in width). The size of spherical cells ranged from $<10$ to $100 \mathrm{~nm}$ in diameter.

\section{DISCUSSION}

GROUND SILICATE RockS

Silicate minerals and rocks contain most of the nutrients that plants require for growth and deve- lopment (van Straaten 2002). Ground silicate rocks have been investigated for their potential to provide these nutrients to plants in various soil environments. The application of ground silicate rocks to highly weathered, low fertility, acid soils has been proposed as alternative to conventional fertilization with water-soluble fertilizers in areas where fertilizers are not available or in organic agriculture (Leonardos et al. 2000, Coroneos et al. 1996). Electron microscopic observations of primitive clay precursors on K-feldspar during microcline weathering under extreme leaching conditions have been reported (Tazaki 1986, Tazaki and Fyfe 1987a, b).

Green-tuff landslide areas are beneficial for rice nutrition revealed in this study. Rice leaf contains high $\mathrm{Si}$ (Fig. 7) which is easily dissolved from soils (Fig. 6) under the ground water characteristics in landslide areas (Fig. 8). Urrutia and Beveridge (1993) have reported the mechanism of silicate binding to the bacterial cell wall in Bacillus subtils. 

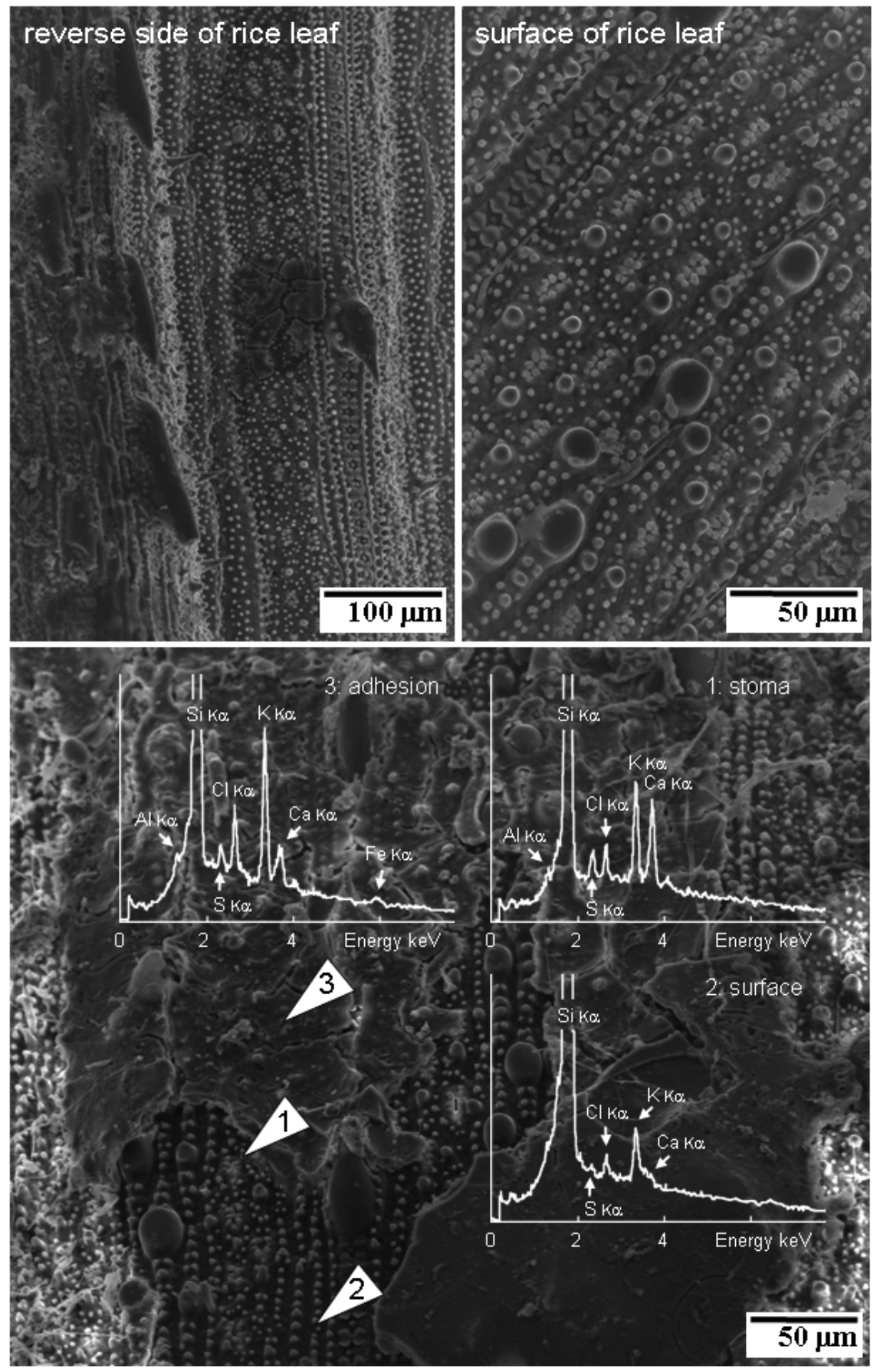

Fig. 7 - Scanning electron microphotographs equipped with energy dispersive analyses (SEM-EDX) of rice leaf collected from landslide areas in Niigata. The stoma, surface, and adhesion area analyses indicated slightly different $\mathrm{K} / \mathrm{Ca}$ ratio between them. 


\begin{tabular}{|c|c|c|c|c|c|c|c|c|c|}
\hline pipe & $\mathrm{pH}$ & $E h(m)$ & $\mathrm{EC}(\mathrm{mS} / \mathrm{cm})$ & $\mathrm{DO}(\mathrm{mg} / \mathrm{l})$ & WT(C) & microorganisms & & $\mathrm{PO}_{4}{ }^{3-}(\mathrm{ppm})$ & $\mathrm{Fe}(\mathrm{ppm})$ \\
\hline 1 & 6.3 & 456 & 0.26 & 6.7 & 17.2 & $\begin{array}{l}\text { diatom, agae, coccus and } \\
\text { bacillus type of bacteria }\end{array}$ & many diato $\mathrm{m}$ & 0.2 & N.D. \\
\hline 2 & 6.2 & 301 & 0.19 & 3.8 & 15.3 & $\begin{array}{l}\text { a kae, diatom, coccus and } \\
\text { bacillus type of bacteria. } \\
\text { filamentous bacteria }\end{array}$ & $\begin{array}{c}\text { mainly } \\
\text { Leptothrix sp. } \\
(50-100 \mu \mathrm{m})\end{array}$ & & \\
\hline 3 & 6.4 & 190 & 0.22 & 3.4 & 14.9 & $\begin{array}{l}\text { Leptothrix sp., alaae, diatom. } \\
\text { coccus and bacillus type of } \\
\text { bacteria, fila mentous } \\
\text { bacteria }\end{array}$ & mainly & & \\
\hline 4 & 6.5 & 140 & 0.30 & 2.1 & 13.0 & $\begin{array}{l}\text { diato m, coccus and bacillus } \\
\text { type of bacteria }\end{array}$ & $\begin{array}{c}\text { small size } \\
(50 \mu \mathrm{m})\end{array}$ & $2-5$ & 20.2 \\
\hline
\end{tabular}
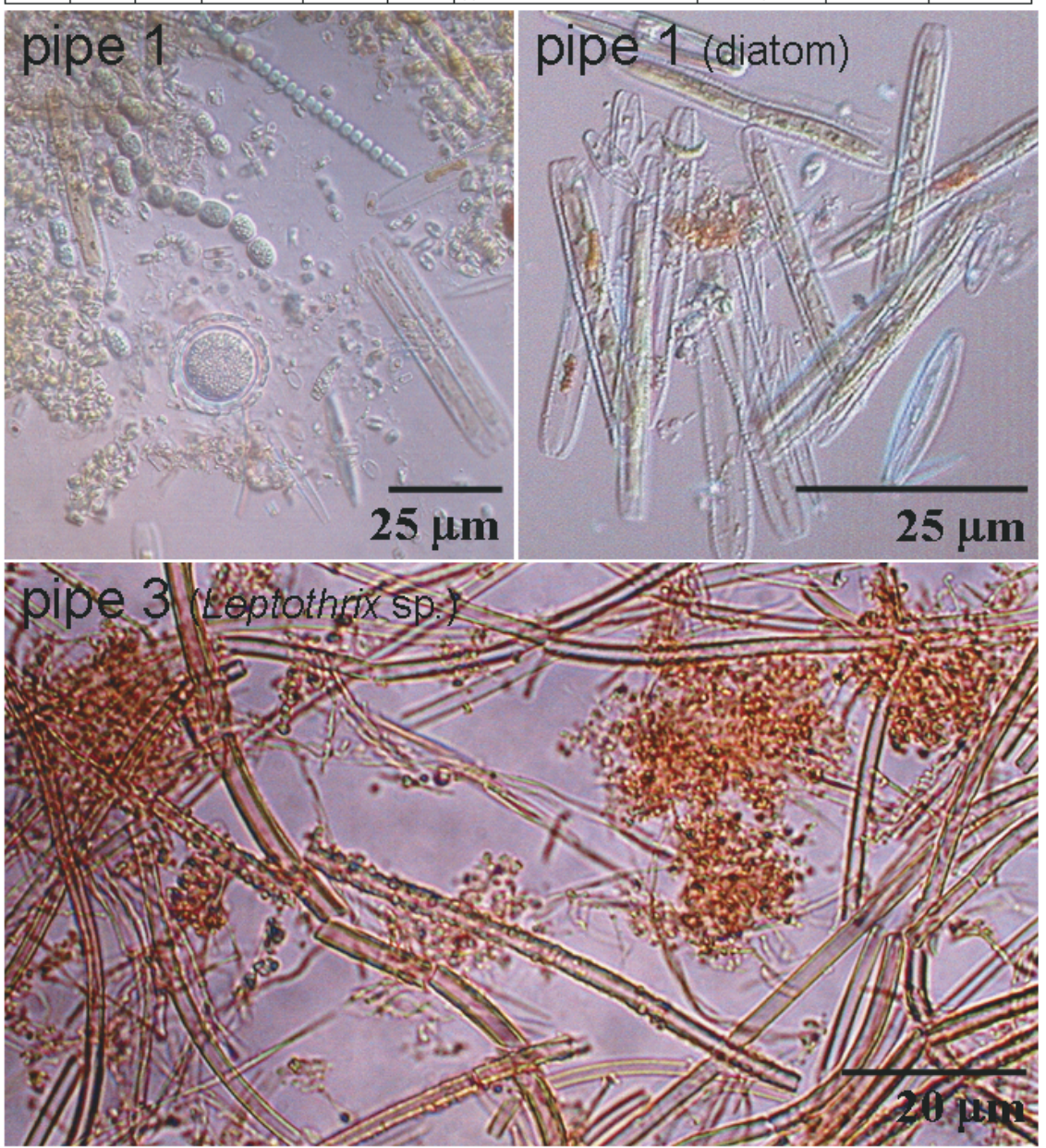

Fig. 8 - Characteristic ground water at landslide areas in Takayanagi in Niigata (upper left) and microorganisms inhabited in the drainage pipes (upper right). Optical micrographs of microorganisms in the microbial mats collected from pipes 1 and 3 (bottom).

Important aspects of landslides are the type of earth material on the slope, topography, climate, vegetation, water, and time. The most common driving force is the weight of the slope materials, and the landslides are a result of an abnormal increase in water pressure in the slope-forming materials (Keller 1992). The green-tuff from volcanic materials ids easily weathered to produce smectite clays with ground water at the landslide area which has both sides of the advantages and disadvantages 
of formation of clay minerals. The weathering process of volcanic glass into allophane was determined by ${ }^{27} \mathrm{Al}$ and ${ }^{29} \mathrm{Si}$ solid state NMR (Hiradate and Wada 2005).

\section{NATURAL K-MINERALS AND ROCKS}

The most commonly used form of $\mathrm{K}$ input in agriculture is potassium salt. These naturally occurring $\mathrm{K}$ fertilizers and mainly obtained from sedimentary potassium (K-salt) deposits providing minerals such as sylvite $(\mathrm{KCl})$ or complex $\mathrm{K}-\mathrm{Mg}$ chlorides and sulfates. The main source of $\mathrm{K}$ for plants growing under natural conditions come from the weathering of $\mathrm{K}$ minerals and organic K-sources such as composts and plant residues. The most important $\mathrm{K}$ minerals are K-feldspar, leucite, K-micas such as biotite, phlogopite, and glauconite, and clays such as illite. K-rich silicate rocks with relatively fast weathering characteristics are leucite-bearing volcanic materials. Bacterial bio-weathering of K-feldspar and biotite in granite have been reported by Ueshima and Tazaki (1998). Mineral surface is control of organic carbon in black shale (Kennedy et al. 2002).

Mica minerals such as phlogopite and biotite contain considerable amounts of $\mathrm{K}_{2} \mathrm{O}$ (usually $>10 \%), \mathrm{MgO}(5-22 \%)$ and $\mathrm{Fe}(5-20 \%)$. Most of these nutrients are part of the silicate structure, in a form not readily available to plants and animals. Electron microscopic and X-ray studies prove that the roots of rape and ryegrass can transform phlogopite into vermiculite, releasing $\mathrm{K}$ and $\mathrm{Mg}$ to the plants. Roots and rhizospheres of plants are active biological weathering agents that transform micas and release $\mathrm{K}$ and other cations (Hinsinger and Jaillard 1993, Hinsinger et al. 1993). Electron microprobe analyses of phlogopite show a narrow range of $\mathrm{K}_{2} \mathrm{O}$ from $9.3 \%$ to $10.4 \%$, and $\mathrm{MgO}$ from 23.1 to $26.5 \%$ (Erickson 1989). In the weathering zone the phlogopite is altered into vermiculite. If there have been attempts to extract $\mathrm{K}$ and $\mathrm{Mg}$ from phlogopite, for example, through biological means (bioprocessing or through plants like rye grass), is unknown.

In this study the rice field in green-tuff composed of smectite contains $\mathrm{Mg}(1 \%), \mathrm{K}(6-7 \%), \mathrm{Ca}$
(4-5\%), and relatively high Fe (18-22\%). The trace element content of this soil is low, with $\mathrm{Ti}(1.7 \%)$ and $\mathrm{Zn}$ concentrations of less than $0.1 \%$. Montmorillonite is the common clay mineral associated with most expansive soils and high CEC. With sufficient water, pure montmorillonite may expand up to 15 times its original volume, but fortunately most soils contain limited amounts of the clay, so it is unusual for an expansive soil to swell beyond 25 to 50 percent. However, an increase in volume greater than 3 percent is considered potentially hazardous (Hart 1974). In this study green-tuff landslide area have been relatively fast weathered to produce abundant smectite and small amount of $\mathrm{K}$ mica minerals, suggesting potentially hazardous. There have been attempts to extract $\mathrm{K}, \mathrm{Mg}$, and $\mathrm{Ca}$ from volcanic materials, are followed by smectite formation with high CEC indicating that the chemical and mineralogical composition of the green-tuff rocks is favorable for direct application in agriculture.

\section{BIOLOGICAL WEATHERING AND BIO-CLAYS}

The principal geologic factors affecting surfacewater runoff and sedimentation include rock and soil type, mineralogy, degree of weathering, and structural characteristics of the soil and rock. Fine grained, dense, clay soils and exposed rock types with few fractures generally allow little water to move downward and become part of the subsurface flows. Therefore the drainage density (length of channel per unit area) is much greater in the shale areas than in the sandstone areas. The shape of a drainage basin is greatly affected by the geologic conditions (Keller 1992). The biosphere is capable of affecting stream flow in several ways. First, vegetation may decrease runoff by increasing the amount of rainfall intercepted and removed by evaporation. Second, streamside vegetation may increase the resistance to flow, which slows down the passage of floodwater. In steep mountain watersheds, many of the pool environments are important for vegetations. Soils with high organic content tend to be relatively cohesive-they reduce surface ero- 
sion and tend to hold water tenaciously-compared to sandy soils, which have low cohesion, high porosity, and high permeability (Chenu and Tessier 1995).

Interactions of clays with microorganisms and bacterial survival in soil have been reported (Theng and Orchard 1995). The above principles and processes suggest that runoff can be variable depending on geologic, physiographic, climatic, and biologic conditions. Such water saturated areas as landslide can produce good vegetations. Organisms are able to form many kinds of minerals, such as clay minerals in volcanic ash soils (Tazaki 2005). Microorganisms produced clay minerals have been identified, and minerals of biological origin contribute significantly to sedimentary deposits (Lowenstam 1981). An interesting example of mineral deposits were produced by biological processes is not only phosphates associated with sedimentary marine deposition, but also organic bio-clays in weathered volcanic materials.

\section{Microbial Sediments}

Almost all living organisms are generally relevant to soil sciences and secondly mineral formation. Organic compounds have a major role in the physical structure of soils. Various organic molecules are able to adsorb ions to form soils. These methods may greatly enhance our studies of the role microorganism play in sediment composition (e.g., mineral formation), their contribution to the sedimentary fabric (e.g. microstructure), and their role in the lithification process (Riding and Awramik 2000). Kuma et al. (1999) suggested that diatom were able to uptake organic-Fe (III) from environments. The banded iron-manganese structures were formed in natural microbial communities (Tazaki 2000). K. Koiwasaki (unpublished data) reported from a mineralogical study of diatom that can take part in the formation of biominerals associated with Fe, As, and S. Microorganisms in microbial mats have their own niche in the geo-aquatic ecosystem. They could accumulate various kinds of elements like $\mathrm{Fe}, \mathrm{Si}$, $\mathrm{S}$, P, etc. from the landslide areas. In this study, Leptothrix ochrecea, a kind of iron oxidized bacte- ria, was found active in the low temperature under reductive condition. Basing on the results of water quality, soil chemistry, soil mineralogy, microscopic observation of microorganisms, it seem that the water characteristics and microbial diversity in landslide area indicate the water-mineral-life interactions suggesting food nutrient chains for crops.

The water channels and convective flow within landslide area has several ramifications. These water channels deliver bulk fluid around, over, and beneath the micro colonies facilitating nutrient delivery and water removal. Thus, diffusion limitation is encountered at the surface of the micro colonies, not at the surface of the biofilm (Stolz 2000). In this study, the channels in the landslide area may also are effect of the transport of bacteria to the surface and the degree of biofilm erosion, sloughing, and terraced rice field.

Bacterial cells can act as a nucleation site for Fe-minerals. Formation of such bacterial mineral composites has been shown to enhance the immobilization of dissolved metals (Tazaki 2005). The implication is that the Fe-bacterial mineralization in the volcanic ash soils and water systems both fosters and augments the solid phase partitioning of metals from solution. The adsorbed silicic acid may act as nucleation site of silica deposition on the surface of microbe (Aramaki et al. 2004, Belkova et al. 2004). In volcanic ash soils may have been formed from biochemical weathering products of cohesive materials, which subsequently controlled the formation of clay-organic complex (Tazaki 2005).

\section{CONCLUSION}

The green-tuffs from volcanic materials are relatively fast weathered to produce smectite clays with high CEC at landslide area which display both sides of the advantages and disadvantages of formation clay minerals. XRD analyses of the soils in landslide area identified the predominant clays as smectite. XRF analyses of the soils at rice field revealed important concentrations of $\mathrm{Mg}, \mathrm{Al}, \mathrm{Si}$, 
$\mathrm{K}, \mathrm{Ca}, \mathrm{Ti}, \mathrm{Mn}$ and Fe which are the main components. SEM-EDX of rice leaf showed a variety of chemical distribution, suggesting that $\mathrm{S}, \mathrm{Cl}, \mathrm{K}$ and $\mathrm{Ca}$ with water play important roles for rice nutrients in green-tuff landslide area. Reddish brown microbial mats form in the drainpipe outlets at landslide water and are rich in $\mathrm{Fe}$ and $\mathrm{PO}_{4}^{3-}$ associated with high EC.

Iron bacteria in the landslide water system have high metabolic rate, therefore minerals are weathered not only by physical and chemical influence but also by the influence of microorganism. Many microorganisms attach to mineral surfaces and show their high impact in the water mineral chemistry in the landslide area, suggesting bacteria play important roles for sustainable agriculture including rice nutrition.

The main source of $\mathrm{K}$ for plants growing under natural conditions comes from not only weathering of K-minerals, but also from organic K-sources such as bacterial products. The above principles and processes suggest that runoff can be variable depending in geologic, climatic and biologic conditions. Such saturated areas can produce good vegetations. Basing on the results of water quality, soil chemistry, soil mineralogy, microscopic observation of microorganisms, it seems that the water characteristics and microbial diversity in landslide area indicate the water-mineral-life interactions suggesting food nutrient chains for crops.

\section{ACKNOWLEDGMENTS}

I would like to express my gratitude to the staffs (Shuichi Shiraishi and Naoto Takahashi) of Nissaku Corporation for their cooperation in this study. Thanks are due to the students of the Tazaki's laboratory (Hiromi Segawa, Kazuhiro Sato, and Hiroki Imanishi) at Kanazawa University for their technical assistance. This study was partially supported by Grant-in-Aid for Science Research from the Ministry of Education, Science, and Culture, Japan (Grant-in-Aid for Scientific Research B).

\section{RESUMO}

As Ilhas Japonesas são cobertas de rochas e solos vulcânicos intemperizados. Terraços de campos de arroz estão comumente localizados em áreas de tufos verdes, as quais são férteis, mas estão geralmente sujeitas a trágicos deslizamentos de terra associados a grandes terremotos. As análises dos solos por difração e fluorescência de raios$\mathrm{X}$ em áreas de deslizamento identificam a predominância de esmectitas, cujos componentes principais são $\mathrm{Mg}, \mathrm{Al}$, $\mathrm{Si}, \mathrm{K}, \mathrm{Ca}, \mathrm{Ti}, \mathrm{Mn}$, e Fe como principais componentes. A palha de arroz mostrou que $\mathrm{S}, \mathrm{Cl}$, K, e Ca têm importantes papéis para a nutrição dos solos dessa área. Sistemas de tubos de deslizamento foram instalados nestas áreas de tufos verdes de forma a reduzir os riscos de deslizamentos. Nas saídas dos tubos de descarga se formou uma esteira de algas microbianas marrom avermelhadas habitadas por bactérias e diatomácea. Os materiais microbianos são ricos em $\mathrm{Fe}$ e $\mathrm{PO}_{4}^{3-}$. As bactérias das águas subterrâneas são ricas em $\mathrm{Fe}$ e têm uma alta taxa metabólica sugerindo que os materiais intemperizados foram produzidos não somente por influência física e química, mas também por micro organismos. Muitos dos microorganismos se prendem às superfícies minerais e apresentam um grande impacto na química mineral da água nas áreas de deslizamento. As bactérias nas áreas de tufos verdes desempenham um importante papel na agricultura sustentável incluindo a nutrição do arroz.

Palavras-chave: tufo verde, terraços de campos de arroz, deslizamento, materiais microbianos.

\section{REFERENCES}

ARAMAKI Y, YoKoYAMA T, OKAUE Y AND WATANABE K. 2004. Chemical adsorption of silicic acid to aluminum combined with cation exchange and chelate resins as model compounds of surface of microbes. Chem Geol 212: 339-349.

Belkova N, Zakharova J AND TAZAKI K. 2004. Fe-Si biominerals in the Vilyuchinskie hot springs, Kamchatka Peninsula, Russia. Int Microbiol 7: 193-198.

BEVERIDGE TJ. 1999. Structures of gram-negative cell walls and their derived membrane vesicles. J Bacteriol 181: 4725-4733. 
Chenu C And Tessier D. 1995. Low temperaturescanning electron microscopy of clay and organic constituents and their relevance to soil micro-structures. Scanning Microscopy 9: 989-1010.

Coroneos C, Hinsinger P AND GiLkes RJ. 1996. Granite powder as a source of potassium for plants: a glasshouse bioassay comparing two pasture species. Fert Res 45: 143-152.

ERIKSON SC. 1989. Phalaborwa: A saga of magmatism, metasomatism and miscibility. In: BELL K. (Ed), Carbonatites, genesis and evolution. Unwin Hyman, London, p. 221-254.

Geological Survey of Japan. 2004. Geochemical maps of Japan. Geological survey of Japan, AIST, 209 p.

HART SS. 1974. Potentially swelling soil and rock in the Front Range Urban Corridor. Colorado Geological Survey. Environ Geol 7: 521.

HiNSINGER P AND JAILlARD B. 1993. Root-induced release of interlayer potassium and vermiculization of phlogopite as related to potassium depletion in the rhizosphere of ryegrass. J Soil Sci 44: 525-534.

Hinsinger P, Elass F, JAILLARD B AND ROBERT M. 1993. Root-induced irreversible transformation of a trioctahedral mica in the rhizosphere of rape. J Soil Sci 44: 535-545.

HiRADATE S AND WADA S. 2005. Weathering process of volcanic glass into allophane determined by 27 Al and 29Si solid state NMR. Clays Clay Miner 53: 401-408.

Holt JG, Krieg NR, Sneath PHA, Staley JT and WILLIAM ST. 1994. Bergey's manual of determinative bacteriology. $9^{\text {th }}$ ed., Williams and Wilkins, USA, $787 \mathrm{p}$

Keller EA. 1992. Environmental Geology, $6^{\text {th }}$ ed., Macmillan Publishing Company, New York, 521 p.

Kennedy MJ, Pkevear DR And Hill RJ. 2002. Mineral surface control of organic carbon in black shale. Science 295: 657-660.

KHRISTOFOROVA NK. 1999. The fundamentals of ecology. Dalnauka, Valadivostok, Russia, 516 p.

KoIDE H. 1955. Landslide sites map of Japan. Taken and compiled from designated Prevention areas map, Government of Prefectures.

Kuma K, TANAKA J AND Matsuna K. 1999. Effect of natural and synthetic organic-Fe (III) complexes in an estuarine mixing model on iron uptake and growth of a coastal marine diatom. Chaetoceros sociale. Mar Biol 134: 761-769.

Leonardos OH, Theodoro SH And Assad ML. 2000. Remineralization for sustainable agriculture: A tropical perspective from a Brazilian viewpoint. Nutr Cycling Agroecosyst 56: 3-9.

LOWENSTAM HA. 1981. Minerals formed by organisms. Science 211: 1126-1130.

Ohta H, Ogawa K and Murakami E. 2003. Quinone profiling of bacterial populations developed in the surface layer of volcanic mudflow deposits from Mt. Pinatsubo (the Philippines). Soil Biol Biochem 35: 1155-1158.

RIDING RE AND AWRAMIK SM. 2000. Microbial sediment. Springer-Verlag: Berlin Heidelberg New York, $331 \mathrm{p}$.

ShoJi S, NANZYo M AND DAHLgRen RA. 1993. Volcanic ash soils: Genesis, properties, and utilization. Elsevier: Netherlands, 288 p.

STOLZ JF. 2000. Structure of microbial mats and biofilms. In: BIDING RE AND AwRAMIK SM (Eds), Microbial sediments. Springer-Verlag: Berlin Heidelberg New York, p. 1-6.

TAZAKI K. 1986. Observation of primitive clay precursors during microcline weathering. Contrib Mineral Petr 92: 86-88.

TAZAKI K. 2000. Formation of banded iron-manganese structures by natural microbial communities. Clays Clay Miner 48: 511-520.

TAZAKI K. 2005. Microbial formation of halloysite. Clays Clay Miner 53: 223-232.

TAZAKI K AND FYFE WS. 1987a. Formation of primitive clay precursors on K-feldspar under extreme leaching conditions. Proceedings of the International Clay Conference, Denver, p. 53-58.

TAZAKI K AND FYFE WS. 1987b. Primitive clay precursors formed on feldspar. Can J Earth Sci 24: 506-527.

THENG BKG AND ORCHARD VA. 1995. Interactions of clays with microorganisms and bacterial survival in soil: A physicochemical perspective. In: HUANG PM AND BERTHELIN J (Eds), Environmental impact of soil component interactions, $333 \mathrm{p}$. 
UESHIMA M AND TAZAKI K. 1998. Bacterial bioweathering of K-feldspar and biotite in granite. Clay Science Japan 38: 68-82.

URrutia MM AND BEVERIDGE TJ. 1993. Mechanism of silicate binding to the bacterial cell wall in Bacillus subtilis. J Bacteriol 175: 1936-1945.
VAn StraAten P. 2002. Rocks for crops: Agrominerals of Sub-Saharan Africa. ICRAF, 338 p. 